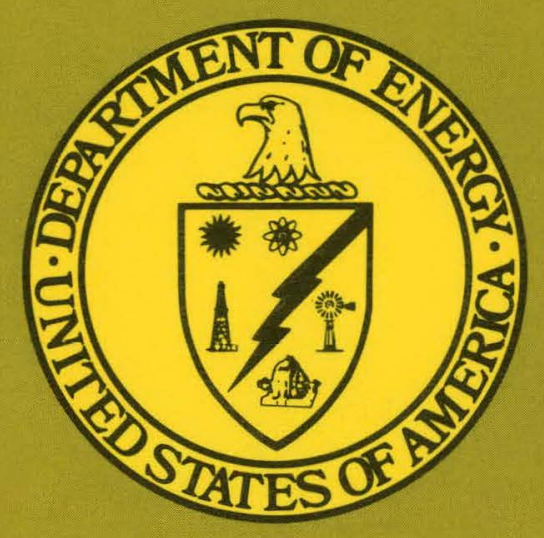

DOE/PETC/TR-80/1

Distribution Category UC-90d

HEAT TRANSFER STUDIES OF PACKED BED REACTORS

By

Norman T. Holcombe

Harold N. Knickle

Paul M. Yavorsky

Date Published - June 1980

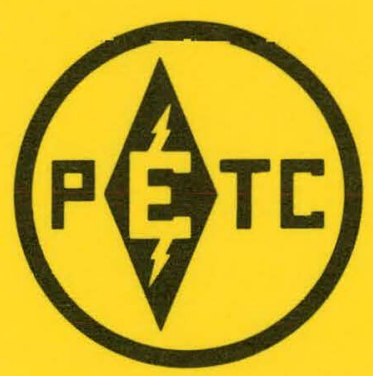

Pittsburgh Energy Technology Center Pittsburgh, Pennsylvania 


\section{DISCLAIMER}

This report was prepared as an account of work sponsored by an agency of the United States Government. Neither the United States Government nor any agency Thereof, nor any of their employees, makes any warranty, express or implied, or assumes any legal liability or responsibility for the accuracy, completeness, or usefulness of any information, apparatus, product, or process disclosed, or represents that its use would not infringe privately owned rights. Reference herein to any specific commercial product, process, or service by trade name, trademark, manufacturer, or otherwise does not necessarily constitute or imply its endorsement, recommendation, or favoring by the United States Government or any agency thereof. The views and opinions of authors expressed herein do not necessarily state or reflect those of the United States Government or any agency thereof. 


\section{DISCLAIMER}

Portions of this document may be illegible in electronic image products. Images are produced from the best available original document. 


\section{DISCLAIMER}

"This book was prepared as an account of work sponsored by an agency of the United States Government. Neither the United States Government nor any agency thereof, nor any of their employees, makes any warranty, express or implied, or assumes any legal liability or responsibility for the accuracy, completeness, or usefulness of any information, apparatus, product, or process disclosed, or represents that its use would not infringe privately owned rights. Reference herein to any specific commercial product, process, or service by trade name, trademark, manufacturer, or otherwise, does not necessarily constitute or imply its endorsement, recommendation, or favoring by the United States Government or any agency thereof. The views and opinions of authors expressed herein do not necessarily state or reflect those of the United States Government or any agency thereof."

This report has been reproduced directly from the best available copy.

Available from the National Technical Information Service, U. S. Department of Commerce, Springfield, Virginia 22161.

Price: Paper Copy $\$ 6.00$

Microfiche $\$ 3.50$ 
Abstract

I Introduction

II Background information 2

III Experimental 3

A. Apparatus . 3

B. Void fraction 3

C. Operating procedure 4

IV Analytical solutions of the concurrent two-phase flow energy . equation applied to a packed bed

A. One dimensional model - one parameter 5

B. Two dimensional model - one parameter 6

C. Two dimensional model - two parameter 7

V Computer program development $\quad 8$

A. MAIN $\quad 8$

B. Subroutine BESSEL $\quad 8$

C. Subroutine ROOT 8

D. Subroutine OPTEMP 8

E. Subroutine FUNC 9

F. Subroutine WTEMP 9

G. Subroutine RTEMP 9

H. Subroutine HEAT 9

VI Results and conclusions $\quad 11$

A. $K$ variation with gas flow rate 11

B. $\mathrm{K}^{\mathrm{e}}$ variation with liquid flow rate 11

C. $\mathrm{H}^{\mathrm{e}}$ variation with gas and liquid rate 12

D. Vâriation of $\mathrm{K}$ and $\mathrm{H}$ with bed height 12

$\begin{array}{ll}E \text {. Correlation of } \mathrm{K}_{\mathrm{e}} \text { and }{ }^{\mathrm{W}} \mathrm{H}_{\mathrm{w}} & 12\end{array}$

$\begin{array}{ll}\text { Acknowledgments } & 14\end{array}$

$\begin{array}{lr}\text { Nomenclature } & 15\end{array}$

$\begin{array}{lr}\text { References } & 17\end{array}$

$\begin{array}{ll}\text { Appendix } & 30\end{array}$ 


\section{ILLUSTRATIONS}

Figure

1 Heat transfer study system schematic

2 Heat transfer reactor model

3 Typical radial temperature profile

4 Axial temperature profile for center of reactor model

5 Typical variation of the effective thermal conductivity with gas mass velocity at constant liquid flow rate

6 Typical variation of the effective thermal conductivity with liquid mass velocity

7 Typical variation of the wall heat transfer with gas flow rate at constant 1 iquid mass velocity

8 Typical variation of the wall heat transfer coefficient with liquid flow rate

9a Entrance effects on $\mathrm{K}_{\mathrm{B}}$

$9 b$ Entrance effects on $\mathrm{H}_{\mathrm{w}}$

10 The predicted versus observed values of the effective thermal conductivity for the correlation:

$$
\mathrm{K}_{\mathrm{e}}=2,000 \mathrm{G}_{1}^{.53} \mathrm{G}_{\mathrm{n}}^{.11}
$$

11 The predicted versus observed values of the wall heat transfer coefficient for the correlation:

$$
\mathrm{H}_{\mathrm{w}}=14,000 \mathrm{G}_{1}^{.62} \mathrm{G}_{\mathrm{n}}^{.042}
$$




\title{
HEAT TRANSFER STUDIES OF PACKED BED COAL LIQUEFACTION REACTORS
}

\author{
Norman T. Holcombe, Harold N. Knickle, and Paul M. Yavorsky \\ Department of Energy \\ Pittsburgh Energy Technology Center \\ P. 0. Box 10940 \\ Pittsburgh, Pennsylvania 15236
}

\begin{abstract}
The effective thermal conductivity $\left(\mathrm{K}_{\mathrm{e}}\right)$ and wall heat transfer coefficient $\left(\mathrm{H}_{\mathrm{w}}\right)$ were determined in a packed bed reactor model over a range of gas mass velocities from 0 to $15,000 \mathrm{~kg} / \mathrm{m}^{2} \mathrm{hr}$, liquid mass velocities from 5,000 to $65,000 \mathrm{~kg} / \mathrm{m}^{2} \mathrm{hr}$, and pressures that simulate coal 1 iquefaction pressures from 1,000 to 4,000 psig. A correlation for $K$ and $H$ was developed for the range of study. Several mathematical models for one and two dimensions, and for one and two parameters, were derived to describe two-phase flow in packed beds. Two flow reglmes are described. The entrance effects for the low liquid flow regime seem to be limited to a length of about ten diameters, while the entrance effects for the high liquid flow seem to extend through the entire length of the column.
\end{abstract}

\section{INTRODUCTION}

Tubular packed bed reactors are often employed for carrying out reactions occurring with porous catalysts. Coal 1 iquefaction reactions are known to be exothermic. In such cases, certain reactor-conditions can promote a state of unstable equilibrium. In this state, small changes in conditions, i.e., feed rate or temperature, will cause serious thermal excursions. This could result in the formation of coke and the eventual blockage of the reactor. Thus, any final reactor design must ensure low sensitivity to operating conditions and prevent undesirable operating regimes in pilot or industrial plants.

The objectives of this study were two-fold. The first objective was to obtain effective thermal conductivities $\left(K_{f}\right)$ and wall heat transfer coefficients ( $H_{w}$ ) for two-phase flow (nitrogen and water) in a packed bed. This entailed measuring the radial and axial temperature profiles for a wide range of mass velocities and pressures that would simulate coal liquefaction conditions. The primary variables were liquid and gas mass velocities and gas densities. The second objective was to develop a theoretical model for use in reactor design analysis, parameter sensitivity study and scale-up predictions of the temperature profile.

If one compares the heat generated in the reaction with the ability of the system to remove heat, based on single-phase correlations (19), one would conclude that the maximum diameter for a stable packed bed coal liquefaction reactor will be approximately 0.15 meters. However, the heat transfer properties of single-phase flow are definitely different from those of two-phase flow, and cold hydrogen can be added to the system to slow down the reaction. Nevertheless, this illustrates the need for heat transfer data for two-phase flow in packed beds. 


\section{BACKGROUND INFORMATION}

Very little heat transfer research has been conducted in two-phase flow and most of this has been in unpacked bubble columns. A review of bubble column research has been written by Mashelkar (11). However, unpacked bubble columns are not very relevant to two-phase flow in packed beds because the packing creates entrance and wall effects for the entire length of the reactor. The hydrodynamics for two-phase downflow in a packed column have been reported by references 4,5 ; and 6 , and for upflow by references $7,8,9$, and 10 . Heat transfer for two-phase downflow has been studied by Weekman and Myers (2) and K. Hashimoto, et al. (12). No literature was found on heat transfer for two-phase upflow in packed beds in the flow regimes of interest.

In the paper of Weekman and Myers, heat transfer resistance near the surface is neglected and only the resistance in the inner sections of the packed bed is considered. An interrelating equation for the overall radial effective thermal conductivity of a gas-1iquid concurrent packed bed was proposed. However, the heat transfer resistance at the wall is large and should not be neglected. K. Hashimoto, et al. (12) adapted the single-phase flow method of Phillips, et al., which included the resistance at the wall to two-phase flow. This method is similar to the method employed in this paper except that Phillips' method assumes a constant wall temperature. In this system, it was felt that the wall temperature varied significantly with height; and thus the approximation of a constant wall temperature was unacceptable and wall temperature variations had to be taken into account. It should be noted that, in any industrial application, the wall temperature will probably vary significantly along the length of the reactor. 
III. EXPERIMENTAL

\section{A. Apparatus}

A schematic 1llustration of the experimental system used in the heat transfer experiments is shown in figure 1 . The reactor model is shown in figure 2. The reactor is $s 1 x$ feet high, has a three-inch inside diameter, and is surrounded by a cooling water jacket. The column is packed with $1 / 4 \times 1 / 4-1$ nch ceramic cylinders. Water and nitrogen are heated in a chamber containing six heating rods and packed with copper shot. Above the heating rods, there is a distributor with a single $1 / 2-1$ nch hole to provide unfform mixing of the hot fluld. A barrier against migration of the copper shot into the reactor was provided by a porous plate located just above the distributor. A six-inch calming section filled with $1 / 4$ $x$ 1/4-1nch cylinders is situated close to the porous plate. The reactor is constructed of 304 stainless steel. Radial temperature profiles were determined using multiple thermocouples containing five individual type $k$ thermocouples. The spacing of the thermocouple positions was $1 / 4-1$ nch. Six of the multiple thermocouples were situated a foot apart along the height of the bed. The first bed thermocouple ie six incheo above the entrance. Another multiple thermocouple was placed at the entrance of the bed. At the exit of the bed, two thermocouples measured the average exit temperature. Bed pressures were measured using pressure transducers situated at five different locations along the height of the bed. The pressure drop was generally between 5 and $15 \mathrm{kPa} / \mathrm{m}$, depending on the mass velocities. There is significant error in this measurement due to substantial preseure fluctuationo in the bcd. The pressure fluctuations were due to the hydrodynamics of two-phase flow, rather than to some experimental artifact such as liquid pumping, since there were no pressure fluctuations for single-phase flow. N1trogen is supplied from a liquid nitrogen storage tank at $1.0 \mathrm{MPa}$ ( $150 \mathrm{psig}$ ), and gas flows were measured separately by two Foxboro orifice gauges. The bed pressure was controlled by a letdown valve at the top of the bed. After the pressure was reduced, the fluid entered a liquid-gas separator and was vented.

B. Void fraction

The average density of the particles was obtained by counting several hundred pellets, weighing them, and then obtalning their volume by water displacement. The model reactor was then filled with a known welght of pellets. The reactor was sealed, and nitrogen and water were passed through the bed for several hours. At this point, the model reactor was opened and more pellets were added to make up for settling. This procedure was repeated several times until no more settling occurred. Since one knew the density of the pellets, the volume of the model reactor, and the welght of pellets in the model reactor, the void fraction could be calculated. Settling of the bed was found to be very important. The settling procedure would change the vold fraction from about 0.35 to 0.25 . 


\section{Operating procedure}

The normal operating procedure was to set the liquid flow first. After the entire bed was wet, the desired nitrogen flow rate and the system pressure were established. At this point, the temperature of the incoming fluid was increased to approximately $60^{\circ} \mathrm{C}$. Only after the entire system remalned constant for at least a half hour were any temperature profiles measured. 
IV. ANALYTICAL SOLUTIONS OF THE CONCURRENT

TWO-PHASE FLOW ENERGY EQUATION APPLIED TO A PACKED - BED (Ref. 15)

\section{A. One dimensional model - no radial dependence - one parameter}

The simplest derivation for the solution of the energy equation when variable wall temperature boundary conditions are applied considers only one dimension. The differential equation is derived assuming no radial variation of temperature. The only "parameter" involved is the wall heat transfer coefficient. The energy balance on a differential volume is

$$
S\left(G_{g} C_{p g}+G_{1} C_{p 1}\right) d t=h_{w}\left(t_{w}(z)-t(z)\right) d A
$$

The relevant boundary condition is

$$
t=t_{0} \text { at } z=0
$$

If a linear variation of the wall temperature is assumed,

$$
t_{w}=t_{w 0}-c \cdot z
$$

the analytical solution is

$$
\begin{aligned}
& t(z)=t_{0} \exp (-z / 2) \\
& +\left(t_{\text {wo }} \text { ac }-c z\right)(1-\exp (-z / a))
\end{aligned}
$$

where

$$
a=\left(R / 2 h_{w}\right)\left(G_{g} C_{P_{g}}+G_{1} C_{P_{1}}\right)
$$

The constant $c$ is the absolute value of the slope of the wall temperature and must be known.

If an exponential variation is assumed for the wall temperature,

$$
t_{w}=t_{\text {wo }} e^{-u z}
$$

the boundary condition is

$$
t=t_{0} \text { at } z=0
$$

and the analytical solution is

$$
\begin{aligned}
& t(z)=t_{0} \exp (-z / a) \\
& +t_{w 0} /(1+a u)(\exp (-u z)-\exp (-z / a))
\end{aligned}
$$


The constant $u$ is the exponential constant which describes the wall temperature variation and must be known.

B. Two dimensional model - one parameter

To account for radial dependence, the differential equation is modified. However, in this case, the parameter is changed to $\mathrm{K}_{\theta}$, the effective thermal conductivity. When conduction is considered only in the radial direction, the energy balance over a differential volume of packed bed is

$$
\left(G_{g} C_{p_{g}}+G_{1} C_{p_{1}}\right) \frac{\partial t}{\partial z}=K_{e}\left(\frac{\partial^{2} t}{\partial r^{2}}+\frac{1}{r} \frac{\partial t}{\partial r}\right)
$$

The relevant boundary conditions are

$$
\begin{aligned}
& t=t_{0} \text { at } z=0 \\
& \frac{\partial t}{\partial r}=0 \text { at } r=0 \\
& t=t_{w} \text { at } r=R
\end{aligned}
$$

Note that the wall temperature is involved only in the application of the boundary conditions.

For a linear wall temperature:

$$
t=t_{\text {wo }}-c z
$$

the analytical solution is

$$
t(r, z)=t_{w o}:-c z+\sum_{n=1}^{\infty} \frac{\sum_{n}^{2}\left(t_{0}-t_{w_{0}}\right)}{B_{n} J_{1}\left(B_{n}\right)} J_{o}(B n p) \exp \left(-B_{n}^{2} z / a\right)
$$

$B_{n}$ is the root of the following equation:

$$
J_{0}\left(B_{n}\right)=0
$$

and

$$
a=\frac{R^{2} \cdot\left(G C_{P_{g}}+G_{1} G_{P_{1}}\right)}{K_{e}}
$$

and

$$
\rho=r / R
$$


C. Two dimension model - two parameter model

More accuracy in predicting temperatures is possible by using a two parameter model. For this case $k_{e}$, the effective thermal conductivity, and $b_{w}$, the wall film coefficient, are used as parameters. The energy baiance over a differential volume of the packed bed is identical to equation 9 . However, the boundary conditions now become :

$$
\begin{aligned}
& t=t_{0} \text { at } z=0 \\
& \frac{\partial t}{\partial r}=0 \text { at } r=0 \\
& h_{w}(t-t)=K_{e}\left(\frac{\partial t}{\partial r}\right)_{R} t r=R
\end{aligned}
$$

For a linear wall temperature, the analytical solution is

$$
\begin{aligned}
& t(r, z)=t_{w o}-c z-(c a / 4)\left(1-r^{2} / R^{2}+2 / B_{i}\right) \\
& +2 B i\left(t_{0}-t_{w o}\right) \sum_{n=1}^{\infty} \frac{J_{0}\left(B_{n} \rho\right) \exp \left(-B_{n}{ }^{2} L / a\right)}{\left(B_{n}{ }^{2}+B i^{2}\right) J_{0}\left(B_{n}\right)} \\
& +2 B i c a \sum_{n=1}^{\infty} \frac{J_{0}\left(B_{n} \rho\right) \exp \left(-B_{n}{ }^{2} z / a\right)}{B_{n}{ }^{2}\left(B_{n}{ }^{2}+B i^{2}\right) J_{0} B_{n}}
\end{aligned}
$$

$B_{n}$ is the root of the following equation:

$$
B_{n} J_{1}\left(B_{n}\right)-B i J_{0}\left(B_{n}\right)=0
$$

and $a$ is given by equation 14 . 


\section{COMPUTER PROGRAM DEVELOPMENT (15)}

A computer program called TEMP was written to analyze the cold model experiments. It is spectific with respect to the geometry and number and location of thermocouples of the experimental cold model. With relatively few changes, it can be generalized to predict the effective conductivity and the wall film coefficient parameters. The main program and the subroutines will be discussed briefly.

A. MAIN

MAIN controls the program and calls for the subroutines when they are needed. The theoretical temperatures as a function of radial position and height are calculated for a given $\mathrm{K}_{e}$ and $\mathrm{h}_{\mathrm{w}}$.

B. Subroutine BESSEL

Subroutine BESSEL calculates the zeroth Bessel function from the following equations:

$$
J_{0}\left(B_{n} \rho\right)=\sum_{n=1}^{\infty} \frac{(-1)^{n+1}\left(1 / 2 B_{n} \rho\right)^{2 n+2}}{(n+1) ! \Gamma(n+2)}
$$

and

$$
J_{0}\left(B_{n}\right)=\sum_{i=1}^{\infty} \frac{(-1)^{n+1}\left(1 / 2 B_{n}\right)^{2 n+2}}{(n+1) ! \Gamma(n+2)}
$$

C. Subroutine ROO'T

Subroutine ROOT calculates the first five roots, B, of equation 18. The actual values of the roots were taken from Carslaw and Jaeger (17) and fitted with quadratic regression as a function of $B i$, the Biot number. For BI In Llie lauge of 1.0 to 4.0 , the expreseion for the first root is:

$$
\mathrm{B}_{\mathrm{n}}=0.827023+0.496367 \mathrm{BI}+0.0568818 \mathrm{Bi}^{2}
$$

\section{Subroutine OPTEMP}

Subroutine OPTEMP is a minimization routine for the two parameters $\mathrm{K}_{e}$ and $\mathrm{h}_{\mathrm{w}}$. It is the search part of minimization. The procedure is based on the work of Nelder and Mead (18). It is an extension of the simplex methods which adapts 1 tself to the local landscape using reflected, expanded, and contracted points to locate the minimum. This program (see reference 16) was chosen because derivatives were not required. Since the method assumes unimodality, different initial values of $\mathrm{K}_{e}$ and $\mathrm{h}_{\mathrm{w}}$ may need
to be tried. 
E. Subroutine FUNC

Subroutine FUNC is the objective function for the search routine in OPTEMP. The function attempts to get the best match of experimental temperatures to calculated temperatures in a least squares sense.

All the temperatures, at each radial and axial position, are used simultaneously in the objective function. With minor modifications, the program TEMP can compute the value of $K_{e}$ and $h_{w}$ at each axial position using all the radial temperatures. This type of calculation would give the variation of $k$ and $h$ as a function of height. It would indicate if a significant entrance ${ }^{\text {w }}$ length effect existed. Calculations at each height are now taking place. The objective function is given by the following equation:

$$
F=\sum_{n=1}^{30}\left(t_{\exp }-t_{c a l c}\right)^{2}
$$

\section{F. Subroutine WTEMP}

Subroutine WTEMP uses linear regression to fit the preheater/ reactor wall temperatures as a function of axial position. Its major output is an intercept wall temperature at the base of the preheater/reactor and the slope of the wall temperatures.

\section{G. Subroutine RTEMP}

Subroutine RTEMP is used to compute the average radial temperatures as a function of axial position using an area average:

$$
\bar{T}(z)=\frac{2 \int_{0}^{R} r t(r, z) d r}{R^{2}}
$$

H. Subroutine HEAT

Subroutine HEAT calculates the wall temperature of the preheater/ reactor. The subroutine first calculates the coolant water bulk temperature. The overall heat transfer coefficient is determined between the coolant water bulk temperature and the preheater/reactor wall temperature using

$$
\mathrm{U}_{\mathbf{i}}=1 /\left\{\left(\mathbf{r}_{0}-\mathbf{r}_{\mathrm{i}}\right) \mathrm{A}_{\mathrm{i}} / \mathrm{k}_{\mathrm{ss}} \mathrm{A}_{1 \mathrm{~m}}+\mathrm{A}_{\mathrm{i}} / \mathrm{h}_{0} \mathrm{~A}_{\mathrm{o}}\right\}
$$

The coolant water film coefficient is determined from the Dittus Boelter equation.

$$
\mathrm{h}=0.023 \frac{\mathrm{k}}{\mathrm{D}_{\mathrm{H}}} \mathrm{R}_{\mathrm{e}}^{0.8} \mathrm{P}_{\mathrm{r}}^{0.4}
$$


The amount of heat transferred through the preheater/reactor wall is determined by the loss of heat the two phase flow suffers as it rises in the preheater/reactor. The heat transfer equation is simply:

$$
Q=U_{i} A_{i}\left\{t_{w}(z)-t_{1 w}(z)\right\}
$$

Since everything is known in this equation except the wall temperature $\left(t_{w}\right)$, the equation is used to calculate $t$. The calculation is repeated over each section of the preheater/reâctor between each axial position of temperature measurement. 


\section{RESULTS AND CONCLUSIONS}

Figure 3 shows a typical radial temperature profile. The experimental temperatures are shown for constant bed height versus radial position. The solid lines are for the theoretical curve fit. As one can see, the curve matches the core temperatures very well and is fairly good near the wal1. Figure 4 shows the axial center temperature profile, which agrees closely with the theoretical. Table 1 in the appendix presents a summary of the data. Water flow rates varied from 5,000 to $65,000 \mathrm{~kg} / \mathrm{m}^{2} \mathrm{hr}$ and nitrogen flows from 0 to $15,000 \mathrm{~kg} / \mathrm{m}^{2} \mathrm{hr}$. Most of the experiments were conducted at $927 \mathrm{kPa}$ ( $120 \mathrm{psig})$, which under coal liquefaction conditions corresponds to a gas density of approximately $27,600 \mathrm{kPa}(4,000 \mathrm{psig})$. Some experiments were also conducted at $513 \mathrm{kPa}(60 \mathrm{psig})$ and $306 \mathrm{kPa}$ ( $30 \mathrm{psig})$. These gas densities correspond to $13,800 \mathrm{kPa}(2,000 \mathrm{psig})$ and $6,900 \mathrm{kPa}(1,000 \mathrm{psig})$, respectively.

The single-phase liquid $K$ and $H$ agree very well with the results reported by $\mathrm{K}$. Hashimoto, et al. (12) and Weekman and Myers (2). The twophase results are higher in this case than reported by $K$. Hashimoto, et al. and by Weekman and Myers. This is to be expected since the differences in packing shape and upflow versus dnwnflow will be much more apparent in two-phase flow than in single-phase flow.

\section{A. Variation with flow conditions}

Figure 5 shows the variations of the effective thermal conductivity with gas mass velocities. The trends are the same for low and high liquid mass velocities. Initially, as the flow rate is increased, the effective thermal conductivity increases markedly, then decreases to about $70 \%-90 \%$ of the maximum value. The trend for liquid flows from approximately $25,000 \mathrm{~kg} / \mathrm{m}^{2} \mathrm{hr}$ to $30,000 \mathrm{~kg} / \mathrm{m}^{2} \mathrm{hr}$ is different. It also increases initially, but upon reaching a maximum, the data becomes so scattered that any decrease is not obvious. A transition between two flow regimes seems to occur at this liquid flow rate. At this flow rate, the bed starts to shift and the settling rate is much faster than at other 1 iquid mass velocities. Pressure fluctuations also change character in this region. Finally, D. Smith (14) has noted a flow transition at slightly less liquid velocity but for pressures near atmospheric.

B. Variation of $\mathrm{K}_{\mathrm{e}}$ with liquid flows

Figure 6 shows a typical variation of $\mathrm{K}_{e}$ with liquid flow rate. The trend is nearly to the square root with respect to $G_{1}$ throughout the range of study and for all the gas flow rates. The dat $a$, however, tend to be scattered in the region of $25,000-30,000 \mathrm{~kg} / \mathrm{m}^{2} \mathrm{hr}$. The dependence of the heat transfer properties on the fluid flow conditions for the region above a liquid flow rate of $30,000 \mathrm{~kg} / \mathrm{m}^{2} \mathrm{hr}$ is probably different from the dependency below $25,000 \mathrm{~kg} / \mathrm{m}^{2} \mathrm{hr}$, but the quantity and the quality of the data above $30,000 \mathrm{~kg} / \mathrm{m}^{2} \mathrm{hr}$ are not sufficient for a definitive answer. 
C. Variation of $\mathrm{H}_{\mathrm{w}}$ with gas flows

The effect of gas flow on the wall heat transfer coefficient, shown in figure 7 , is different than on the effective thermal conductivity. Initially, the wall heat transfer coefficient increases with the addition of gas. Then additional gas causes no further increases. As with the effective thermal conductivity, the wall heat transfer coefficient shows more scatter in the 1 iquid region of $25,000-30,000 \mathrm{~kg} / \mathrm{m}^{2} \mathrm{hr}$.

The variation of the wall heat transfer coefficient with liquid mass velocity (figure 8) is essentially the same as that of the effective thermal conductivity. It is nearly to the one-half power of the liquid mass velocity except for some scatter in the liquid region $25,000-30,000 \mathrm{~kg} / \mathrm{m}^{2}$ hr.

D. Variation of $\mathrm{K}_{\mathrm{e}}$ and $\mathrm{H}_{\mathrm{w}}$ will bed lieight

In the initial derivation, $K_{e}$ and $H$ were assumed to be constant throughout the bed. However, one can chonose to perform the calculation on various lengths of the reactor. For instance, the calculation may be applied to the region from the entrance to the first thermocouple, then the entrance to the second thermocouple, etc. In this manner, one can obtain an indication of the variation of $\mathrm{K}_{\text {and }} \mathrm{H}$ as a function of bed height. Figures $9 a$ and $9 b$ show the variation of $\mathbb{R}_{e}$ and $H$ for $t$ wo general types of flow patterns. Within the accuracy of these experiments, $K_{e}$ and $H$ have the same bed height dependence with flows. There seem to be two băsic types of behavior. For liquid flows less than $25,000 \mathrm{~kg} / \mathrm{m}^{2} \mathrm{hr}, \mathrm{K}$ or $H_{w}$ will start low, increase, and then level off as the bed helght increwases. This type of behavior indicates a stagnant volume at the bottom of the reactor with the remainder of the bed fairly uniform. The other type of behavior which occurs for 1 iquid flows above $30,000 \mathrm{~kg} / \mathrm{m}^{2} \mathrm{hr}$ does not reach a constant $\mathrm{K}_{e}$ or $\mathrm{H}_{\mathrm{W}}$. This indicates extensive entrance and/or exit effects throughout the entire length of the bed.

E. Correlation of $\mathrm{K}_{\mathrm{e}}$ and $\mathrm{H}_{\mathrm{w}}$

The effective thermal conductivity and lit wall heat tranefer rof fficient were correlated for two-phase flow and $927 \mathrm{kPa}(120 \mathrm{psig})$. These correlations are strictly empirical; and cannot be applied to very low gas flows. $K_{e}$ was found to correlate to the formula:

$$
\mathrm{K}_{\mathrm{e}}=2,000 \mathrm{G}_{1}^{0.53 \mathrm{G}_{\mathrm{n}}}{ }^{-0.11}
$$

Figure 10 shows the predicted versus observed values for $\mathrm{K}_{e}$. Considering the range of conditions, the correlations are falrly good. Equation 27 correlates two-phase flow very well for high gas mass velocities and is 
generally within $20 \%$ for lower gas mass velocities. $H_{w}$ was found to correlate to the formula:

$$
\mathrm{H}_{\mathrm{w}}=14,000 \mathrm{G}_{1}^{0.62} \mathrm{G}_{\mathrm{n}}^{0.04}
$$

Figure 11 shows the predicted versus the observed values for $H_{\mathrm{w}}$. The correlation for $H_{w}$ indicates an almost negligible dependence of $H_{w}$ on the gas flow rate. The correlation is not as good as that of $\mathrm{K}_{e}$, but ${ }^{\mathrm{w}}$ generally predicts $H_{\text {w }}$ to within $20 \%$ over the entire range of interest. While the correlations were developed with only $927 \mathrm{kPa}(120$ psig) data, the correlations seem to agree well with the $513 \mathrm{kPa}(60 \mathrm{psig}$ ) and $206 \mathrm{kPa}$ (30 psig) experiments. There seems to be little, if any, dependence of $\mathrm{K}_{e}$ and $\mathrm{H}_{\mathrm{w}}$ on pressure in the range of this study. 


\section{ACKNOWLEDGMENTS}

The contributions of Dr. Harold F. Chambers ${ }^{1}$ to the conception of the project and the initial design of the experimental apparatus are gratefully acknowledged. In addition, we would like to thank Mr. Daniel $\mathrm{J}$. Fauth ${ }^{2}$ for his assistance during the construction and data acquisition phases of the project.

1 Branch Chief, Dilute-Phase Hydrogenation

2 Research Equipment Operat or 
NOMENCLATURE

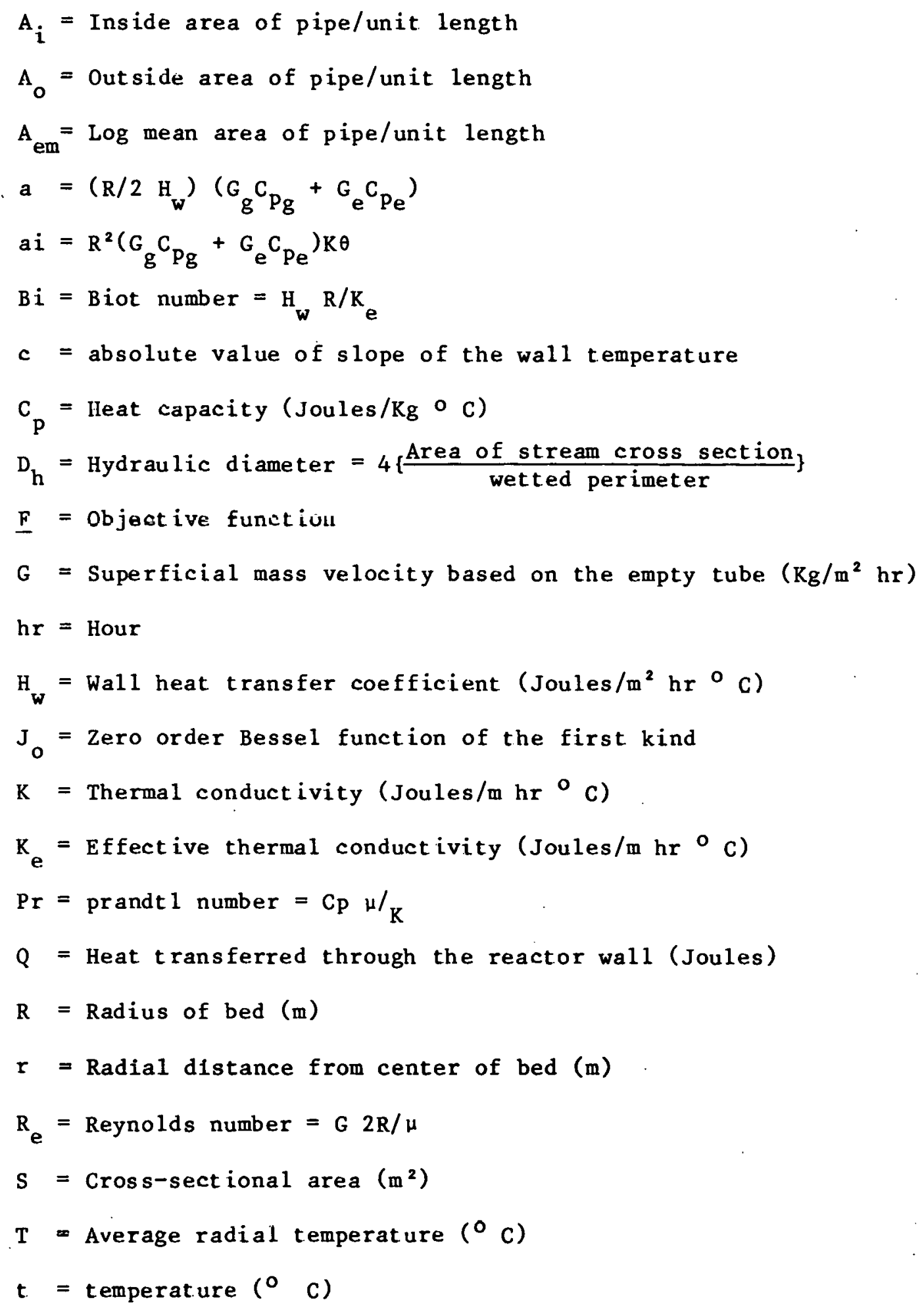


$u=$ Exponential constant which describes the wall temperature variation

$\mathrm{U}=$ overall heat transfer coefficient (Joules $/ \mathrm{m}^{2} \mathrm{hr}{ }^{\circ} \mathrm{C}$ )

$z=$ Bed height (m)

\section{Subscripts}

$$
\begin{aligned}
& \mathbf{g}=\text { Gas } \\
& \mathbf{1}=\text { Liquid } \\
& \mathbf{n}=\text { Nitrogen } \\
& \mathbf{s s}=\text { Stainless stee } 1 \\
& \mathbf{w}=\text { Wall } \\
& \text { wo = Wall at entrance }
\end{aligned}
$$

Greek Symbols

$$
\begin{aligned}
& \mu=\operatorname{viscosity}(\mathrm{Kg} / \mathrm{m} \mathrm{hr}) \\
& \rho=r / R
\end{aligned}
$$


REFERENCES

1. DeWasch, A. P., and G. F. Froment. Heat Transfer in Packed Beds. Chemical Engineering Science, v. 27, 1972, pp. 567-576.

2. Weekman, Jr., Vern W., and John E. Myers. Heat Transfer Characteristics of Concurrent Gas-liquid Flow in Packed Beds. AIChE Journal, v. II, No. 1, 1965, pp. 13-17.

3. Coberly, C. A., and W. R. Marshall, Jr. Temperature Gradients in Gas Streams Flowing through Fixed Granular Beds. Chemical Engineering Progress, v. 47, No. 3, March 1951, pp. 141-150.

4. Sato, Y., T. Hirose, F. Takahashi, and M. Toda. Pressure Loss and Liquid Holdup in a Packed Bed Reactor with Cocurrent Gas-Liquid Downflow. J. Chem. Engineering, Japan, v. 6, No. 2, 1973, pp. 147-152.

5. Sato, Y., T. Hirose, F. Takahashi, M. Toda, and Y. Hashiguchi. Flow Pattern and Pulsation Properties of Cocurrent Gas-Liquid Downflow in Packed Beds. J. Chem. Engineering, Japan, v. 6, No. 4, 1973, pp. 315-319.

6. Weekman, V. W., and J. E. Meyers. Fluid Flow Characteristics of Cocurrent Gas-Liquid Flow in Packed Beds. AIChE Journal, v. 10, no. 6, 1964, pp. 951-957.

7. Sato, Y., T. Hirose, and T. Ida. Upward Cocurrent Gas-Liquid Flow in Packed Beds. J. Chem. Engineering, Tapan, v. 33, 1974, pp. 534.535.

8. Turpin, J. L., and R. L. Huntington. Prediction of Pressure Drop for Two-Phase, Two-Component Cocurrent Flow in Packed beds. AIChE Journal, v. 13, 1967, pp. 1196-1202.

9. Stiegel, G. J., and Y. T. Shah. Backmixing and Liquid Holdup in a Gas-Liquid Cocurrent Upflow Packed Column. Industrial Engineering Chemistry, Process Des. Dev., v. 16, No. 1, 1977, pp. 37-43.

10. Eisenklam, P., and L. H. Ford. Cocurrent Two-Phase Flow through Packed Beds. Proc. Symposium on the Interaction between Fluids and Particles, London: Instn. Chem. Engineers, June, 1962, pp. 333-342.

11. Mashelkar, R. A. Bubble Columns. British Chemical Engineering, v. 15, No. 10,1970 , Pp. 1297-1304.

12. K. Hashimoto, K. Muroyama, K. Fujihoshi, and S. Nagata. Effective Radial Thermal Conductivity in Cocurrent Flow of a Gas and Liquid through a Packed Bed. International Chemical Engineering, v. 16, No. 4,1976 , pp. 720-726.

13. Phillips, B. D., F. W. Leavitt, and C. Y. Young. Chemical Engineering Progress, Symposium Series 59, No. 41, 1956, p. 114. 
14. Smith, Dennis. Personal communication.

15. Knickle, Harold N. Thermal and Hydrodynamic Characteristics of Two-Phase Flow through Packed Beds. 1977 Research Participation Program, Oak Ridge Associated Universities.

16. Kuester, J. L., and J. H. Mize. Optimization Techniques with Fortran. McGraw Hil1, 1973, p. 298.

17. Carslaw, H. S., and J. C. Jaeger. Conduction of Heat in Solids. Second Edition, Oxford University Press, 1959.

18. Nelder, J. A., and R. Mead. A Simplex Method for Function Minimization. Computer Journal 7, 1964, pp. 308-313.

19. Brenner, H., D. C. Priese, and B. Fitch. Combined 3rd and 4th Quarterly Report 8, December 1, 1975-May 31, 1976. ERDA Contract No. E $(36-2)-0056$. 


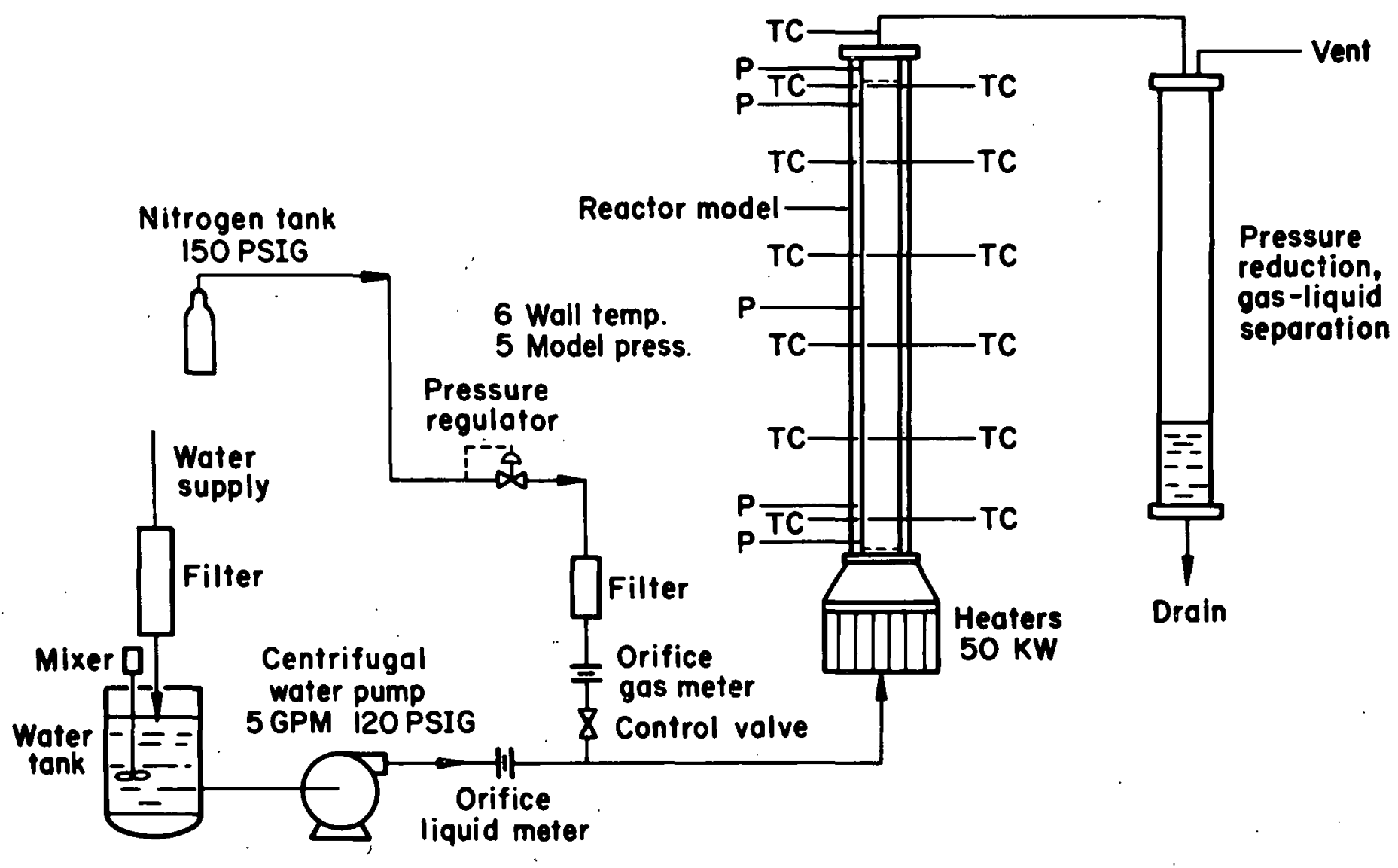

Figure 1- Heat transfer study system schematic. 


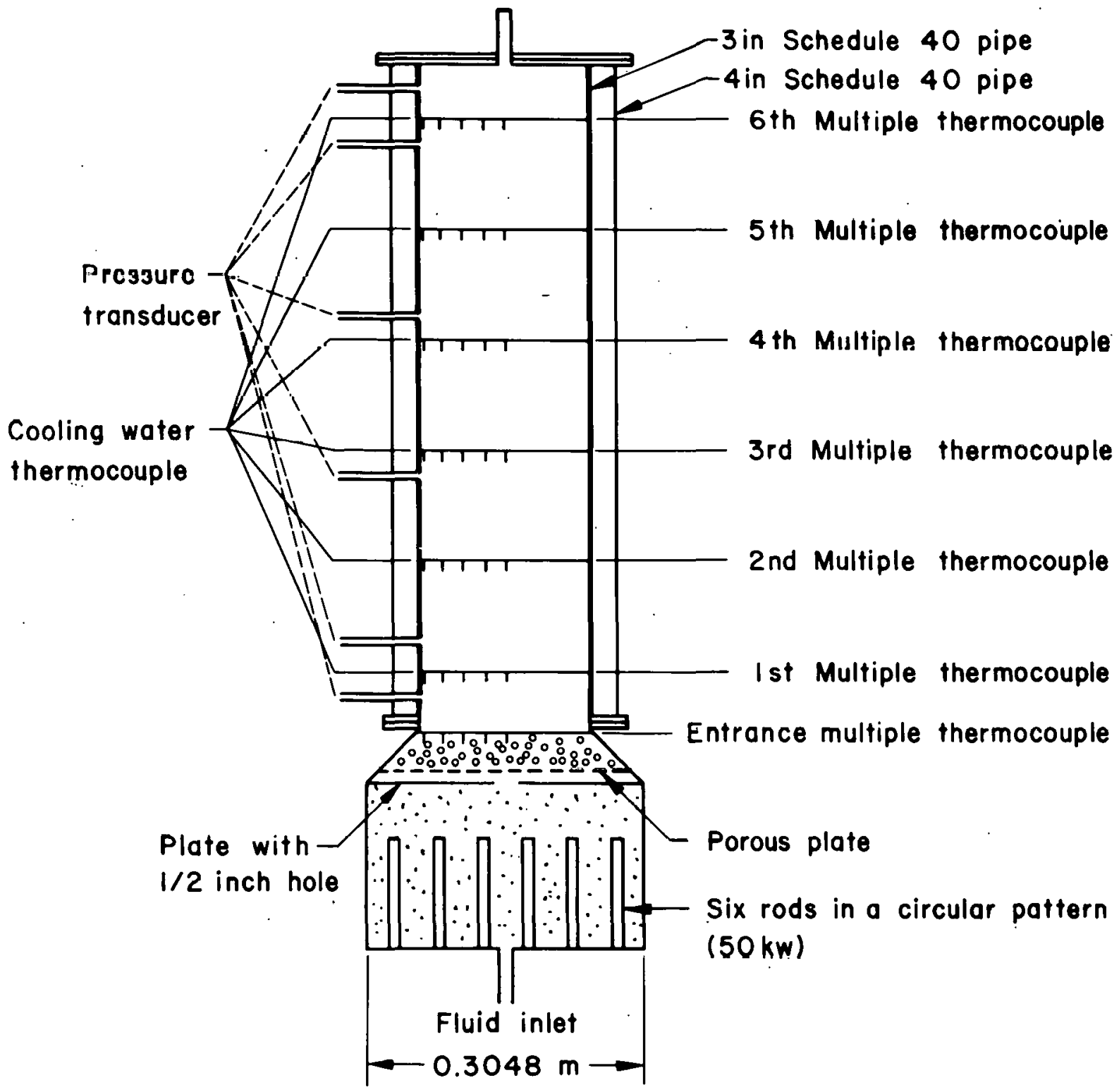

Figure 2 - Heat transfer reactor model 


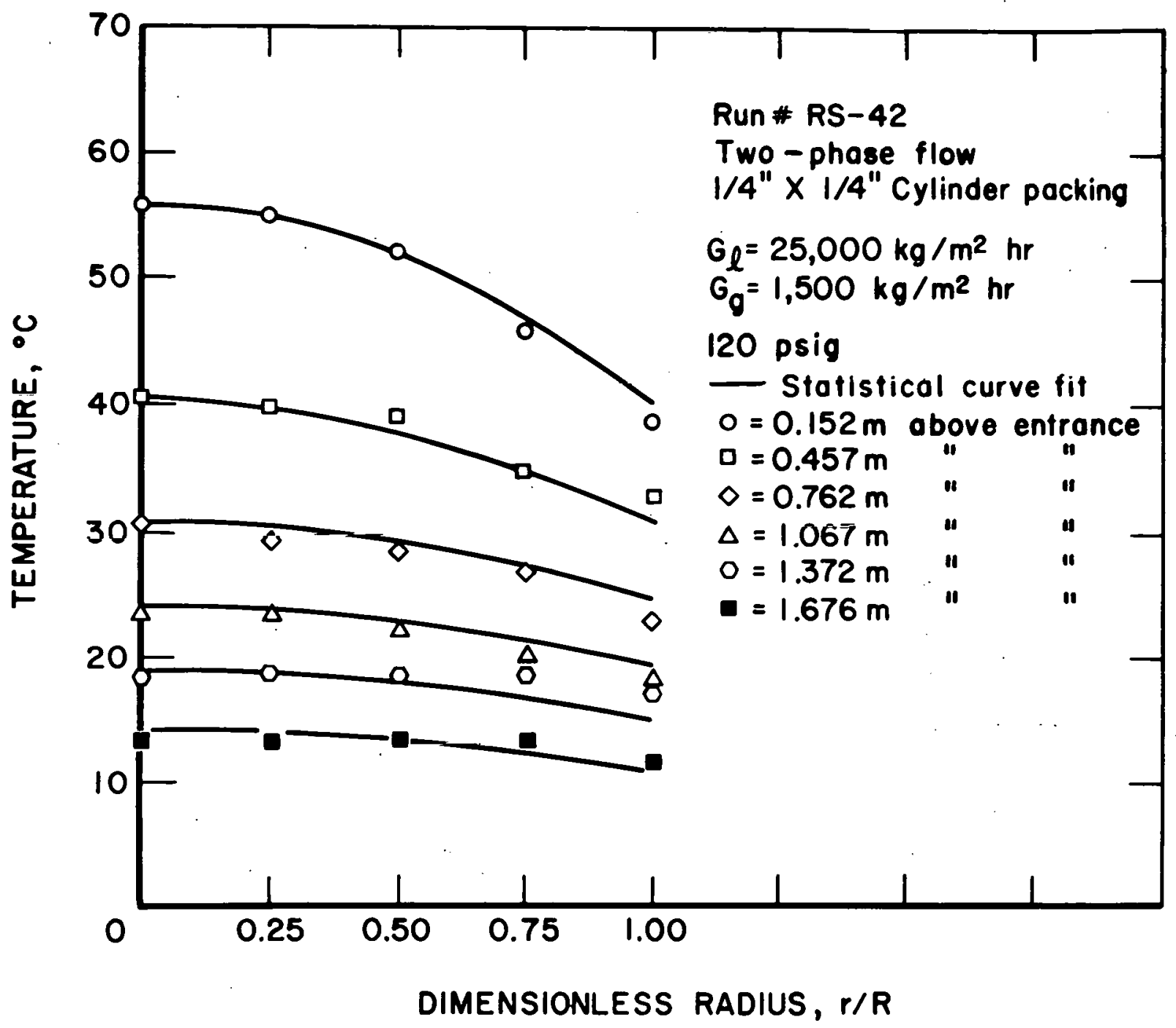

Figure 3 -Typical radial temperature profile

$$
12-6-78 L-16351
$$




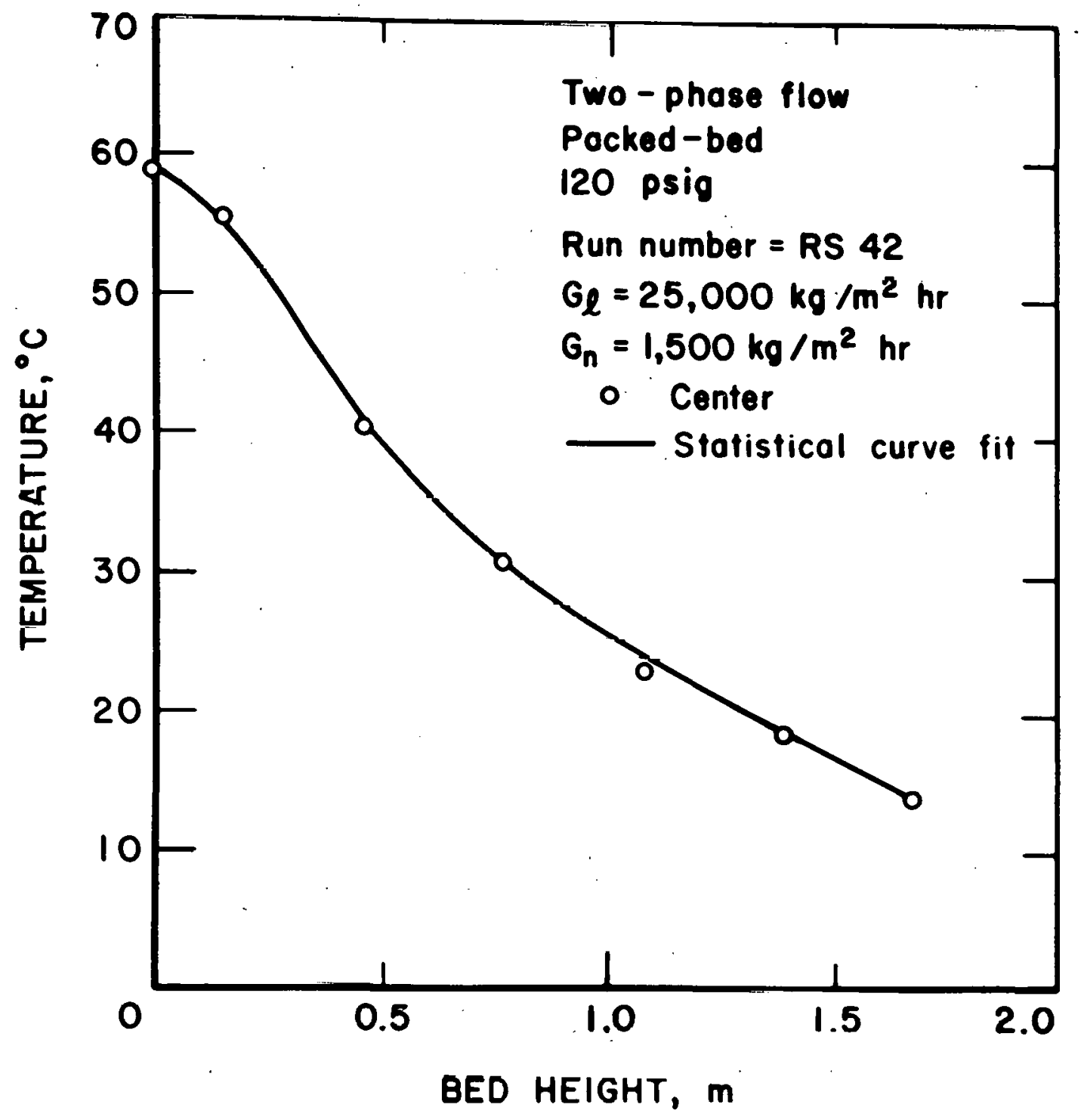

Figure 4-Axial temperature profile for center of reactor model 


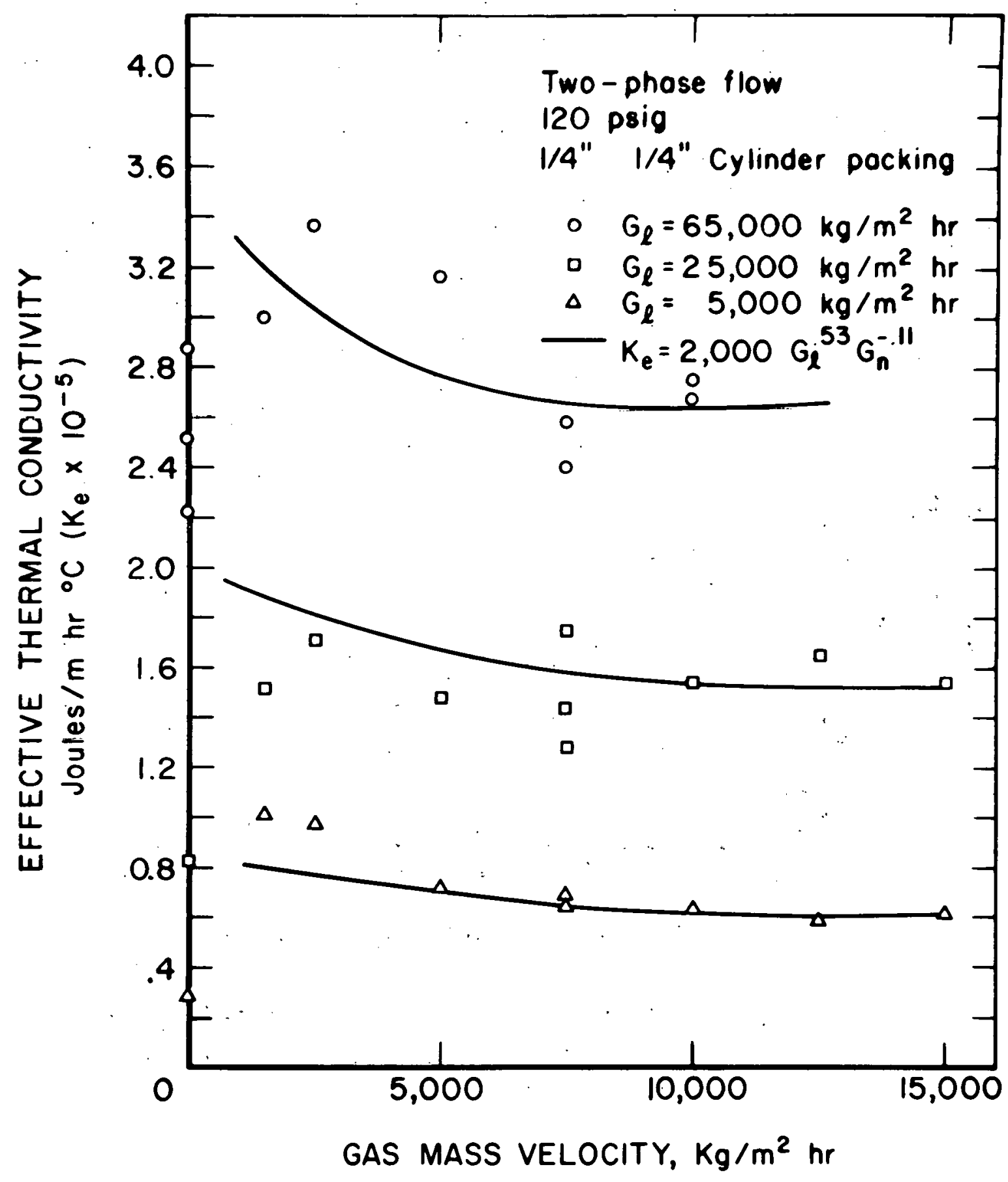

Figure 5-Typical variation of the effective thermal conductivity with gas mass velocities of constant liquid mass velocity. 


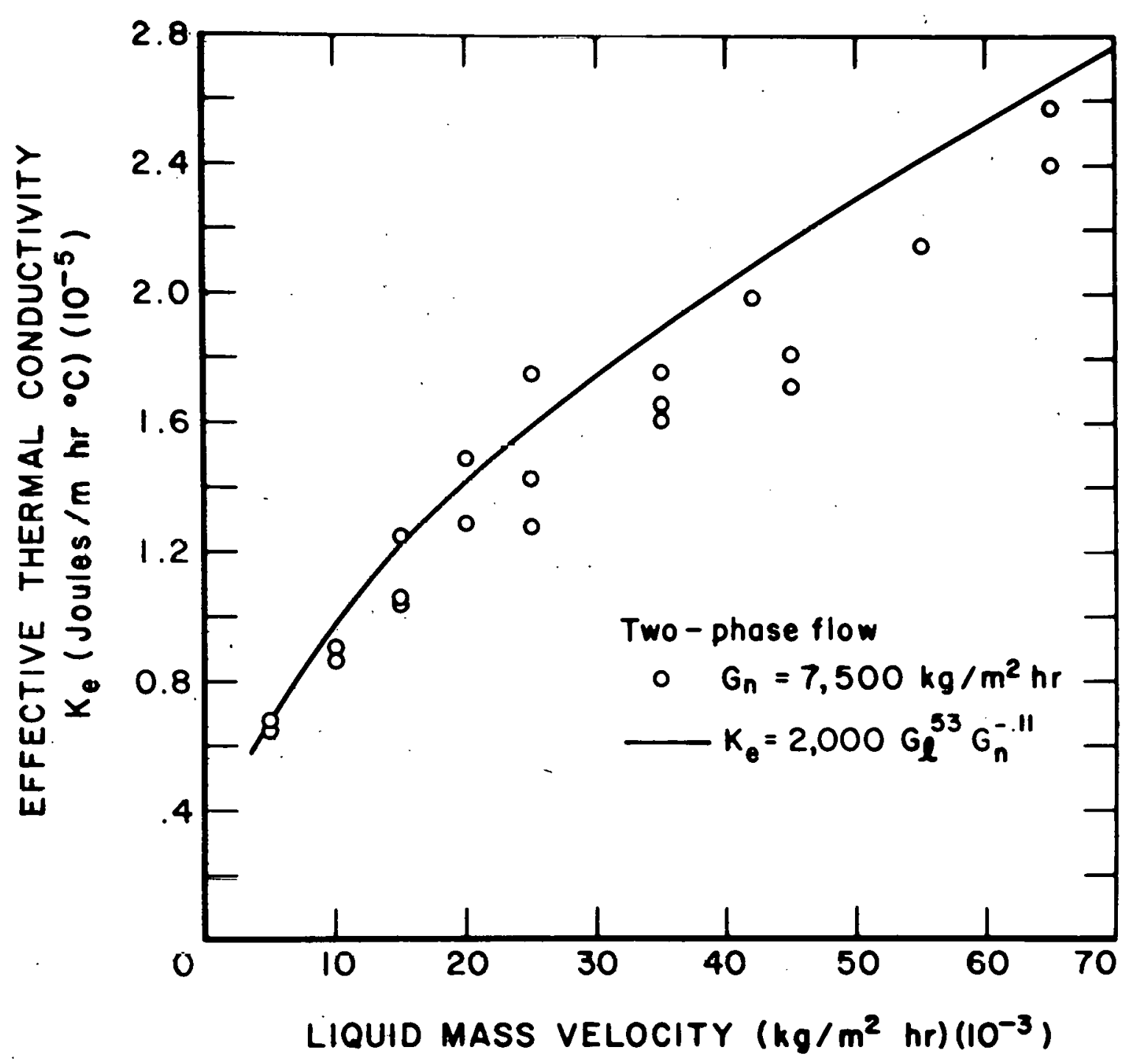

Figure 6-Typical variation of the effective thermal conductivity with liquid mass velocity 


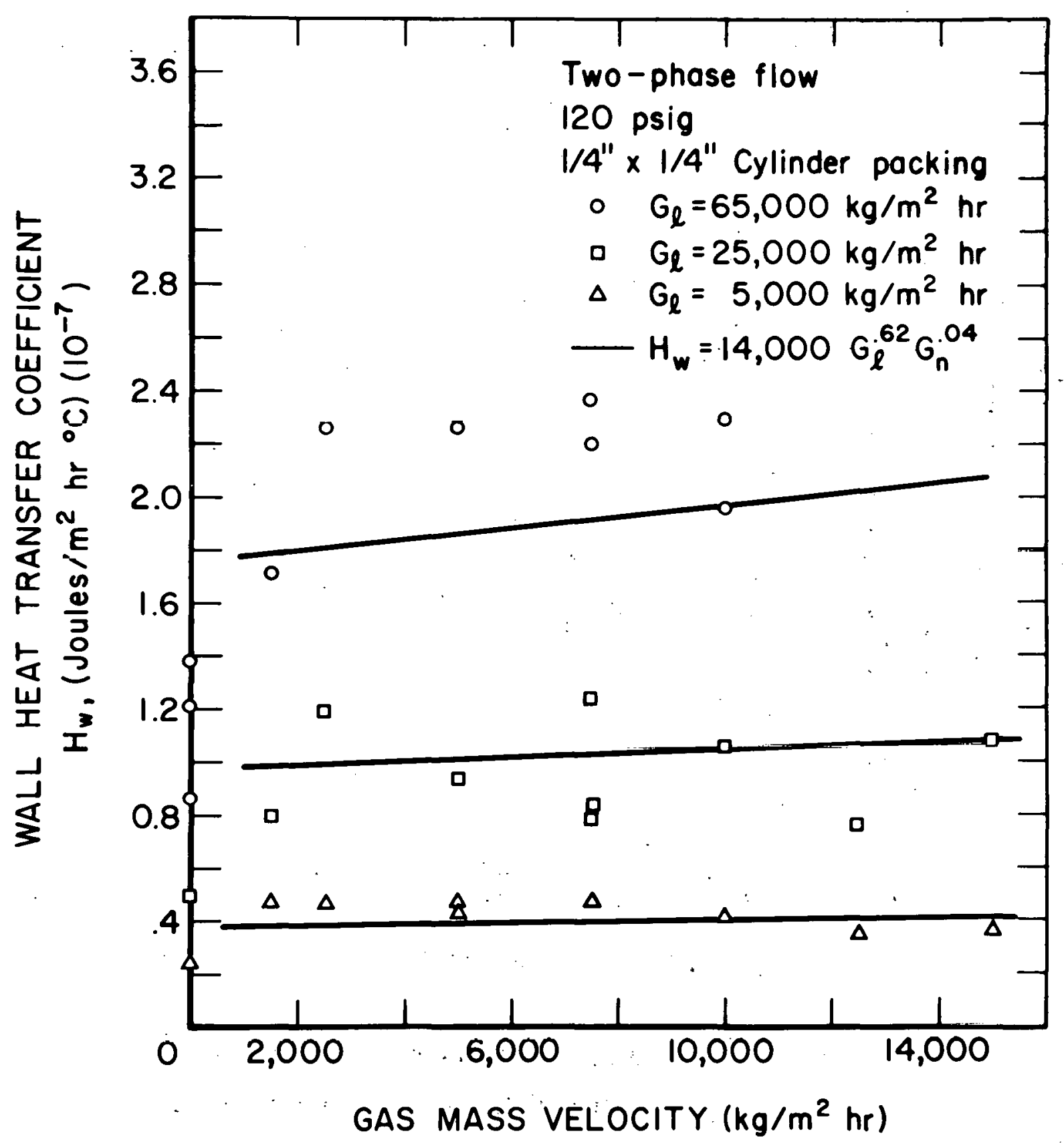

Figure 7-Typical variation of the wall heat transfer with gas mass velocity at constant liquid flow rate.

$$
12-6-78 \quad L-16355 A
$$




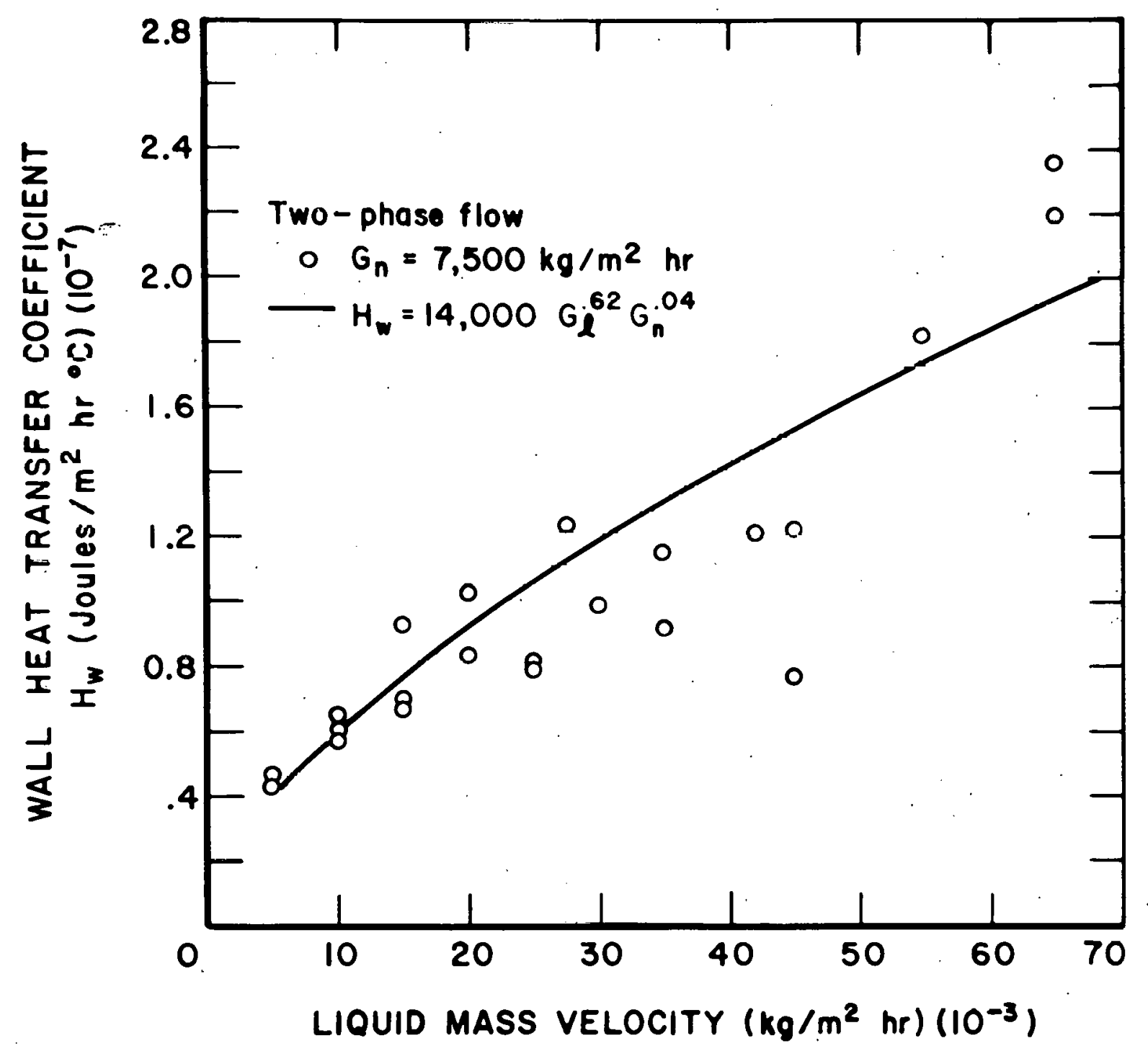

Figure 8-Typical variation of the wall heat transfer - coefficient with liquid mass velocity 


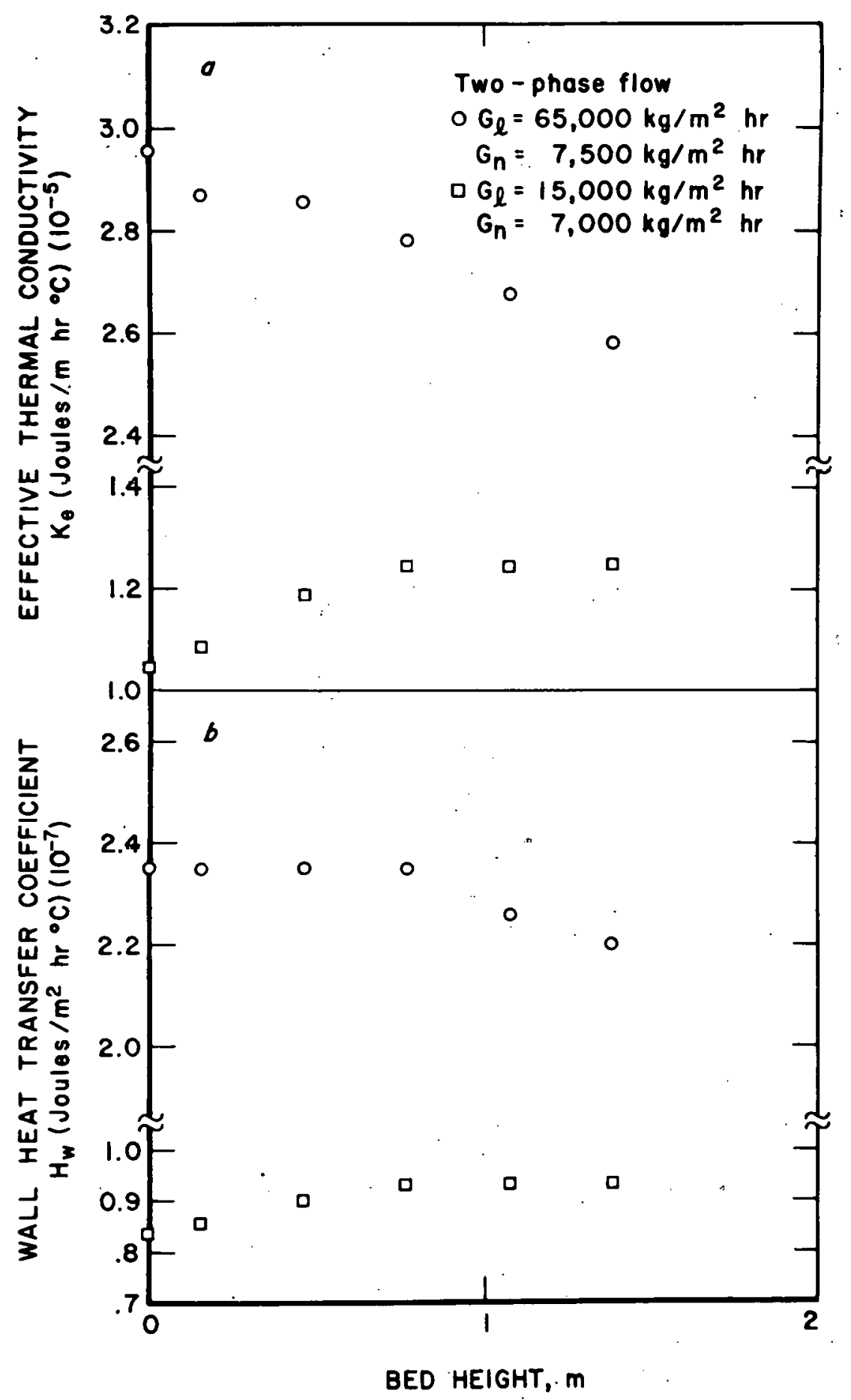

Figure 9 -Entrance effects on $K_{0}(a)$ and $H_{w}(b)$ 


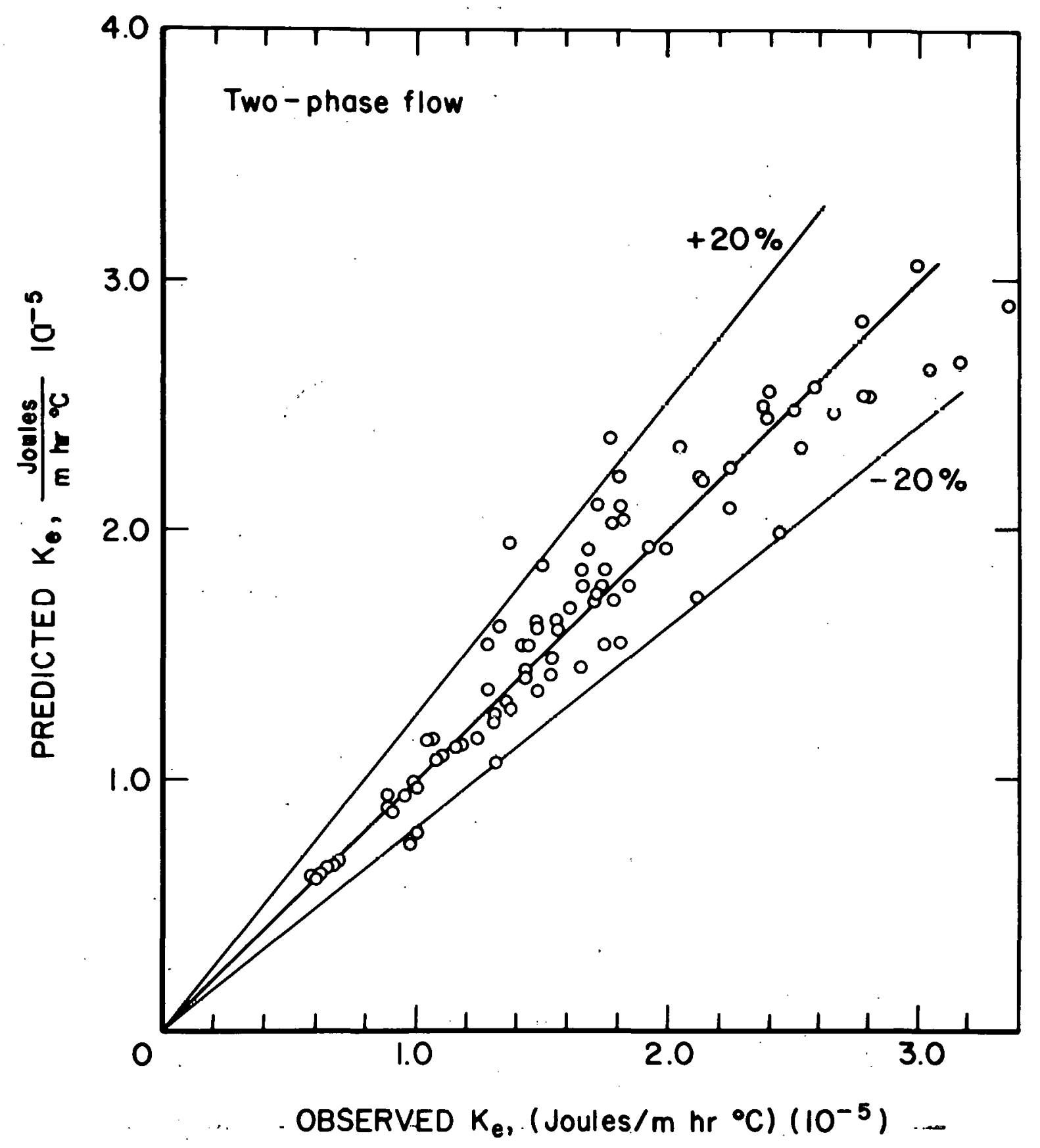

Figure 10 - The predicted versus observed values of the effectivity thermal conductivity for the correlation $K_{e}=1984 G_{l} .53 G_{n}^{-.11}$

12-6-78 L-16358 


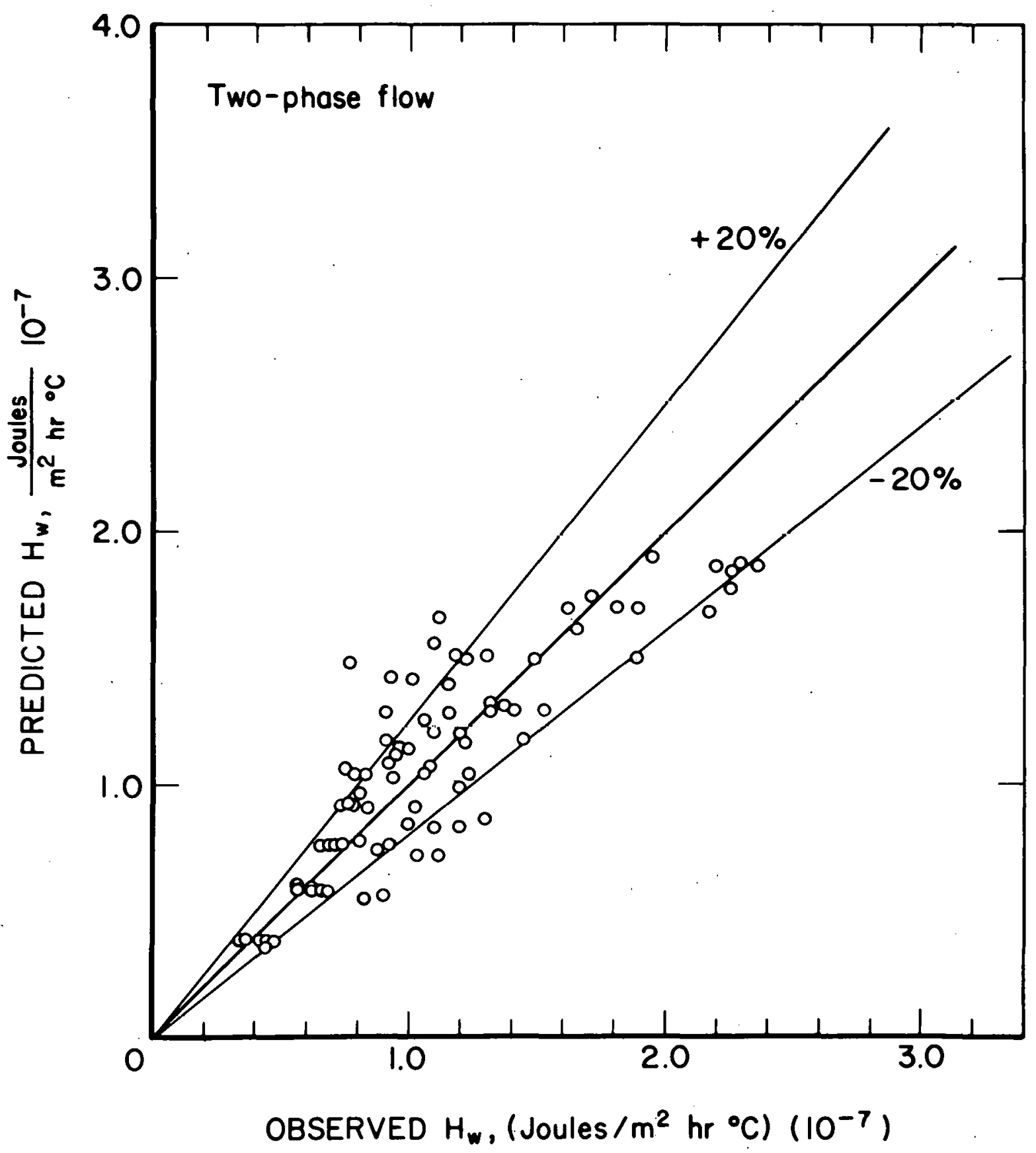

Figure II - Predicted versus observed values of the wail heaf transfer coefficient for the correlation $H_{w}=14,000 G_{R}^{.62} G_{n}^{.042}$

12-6-78 L-16359 
APPENDIX

TABLE I.- Results of heat Transfe: Studies

\begin{tabular}{|c|c|c|c|c|c|c|c|}
\hline $\begin{array}{c}\begin{array}{c}\text { Run } \\
\text { Number }\end{array} \\
\end{array}$ & $\begin{array}{l}\text { Pres- } \\
\text { sure } \\
\mathrm{KPa} \\
\end{array}$ & $\begin{array}{l}\text { Inlet } \\
\text { Temp } \\
\circ \mathrm{C} \\
\end{array}$ & $\begin{array}{l}\text { Exit } \\
\text { Temp } \\
\circ \mathrm{C} \\
\end{array}$ & $\begin{array}{c}\text { Liquid Mass } \\
\text { Velocity } \\
\mathrm{Kg} / \mathrm{m}^{2} \mathrm{hr} \\
\end{array}$ & $\begin{array}{l}\text { Gas Mass } \\
\text { Velocity } \\
\mathrm{Kg} / \mathrm{m}^{2} \mathrm{hr} \\
\end{array}$ & $\begin{array}{c}\text { Effactive Thermal } \\
\text { Conductivity } \\
\text { Jodles/m hr o c } \\
\left(\mathrm{X}_{1} 10^{-5}\right) \\
\end{array}$ & $\begin{array}{c}\text { Wall Heat Transfer } \\
\text { Cuefficient } \\
\text { Joules } / \mathrm{m}^{2} \mathrm{hr} \text { o } \mathrm{C} \\
\left(\mathrm{X} 10^{-7}\right) \\
\end{array}$ \\
\hline $\begin{array}{l}\text { RS-1 } \\
\text { RS-2 } \\
\text { RS-3 } \\
\text { RS-4 } \\
\text { RS-5 } \\
\text { RS-6 } \\
\text { RS-7 } \\
\text { RS-8 } \\
\text { RS-9 } \\
\text { RS-10 } \\
\text { RS-11 } \\
\text { RS-12 } \\
\text { RS-13 } \\
\text { RS-14 } \\
\text { RS-15 } \\
\text { RS-16 } \\
\text { RS-17 } \\
\text { RS-18 } \\
\text { RS-19 } \\
\text { RS-20 } \\
\text { RS-21 } \\
\text { RS-22 } \\
\text { RS-23 } \\
\text { RS-24 } \\
\text { RS-25 } \\
\text { RS-26 } \\
\text { RS-27 } \\
\text { RS-28 } \\
\text { RS-29 } \\
\text { RS-30 }\end{array}$ & $\begin{array}{l}927 . \\
\text { do. } \\
\text { do. } \\
\text { do. } \\
\text { do. } \\
\text { do. } \\
\text { do. } \\
\text { do. } \\
\text { do. } \\
\text { do. } \\
\text { do. } \\
\text { do. } \\
\text { do. } \\
\text { do. } \\
\text { do. } . \\
\text { do. } \\
\text { do. } \\
\text { do. } \\
\text { do. } \\
\text { do. } \\
\text { do. } . \\
\text { do. } \\
\text { do. } \\
\text { do. } \\
\text { do. } \\
\text { do. } \\
\text { do. } \\
\text { do. } \\
\text { do. } \\
\text { do. }\end{array}$ & $\begin{array}{l}58.0 \\
58.7 \\
58.7 \\
53.2 \\
57.1 \\
63.0 \\
67.9 \\
55.0 \\
55.5 \\
58.9 \\
56.3 \\
62.0 \\
52.6 \\
66.0 \\
59.5 \\
65.7 \\
62.0 \\
61.2 \\
64.2 \\
61.7 \\
60.3 \\
54.8 \\
57.3 \\
58.4 \\
55.0 \\
57.5 \\
57.5 \\
59.1 \\
57.5 \\
62.3\end{array}$ & $\begin{array}{r}14.3 \\
15.7 \\
16.1 \\
17.8 \\
11.1 \\
9.7 \\
7.8 \\
25.2 \\
18.2 \\
21.9 \\
11.2 \\
9.5 \\
11.7 \\
9.3 \\
12.8 \\
9.0 \\
8.5 \\
9.6 \\
15.5 \\
14.5 \\
13.5 \\
10.2 \\
10.0 \\
9.8 \\
11.8 \\
17.8 \\
16.8 \\
14.8 \\
9.5 \\
10.3\end{array}$ & $\begin{array}{r}35,000 \\
25,000 \\
20,000 \\
42,100 \\
15,000 \\
15,000 \\
10,000 \\
45,000 \\
35,000 \\
25,000 \\
15,000 \\
10,000 \\
20,000 \\
5,000 \\
10,000 \\
10,000 \\
10,000 \\
10,000 \\
10,000 \\
15,000 \\
15,000 \\
15,000 \\
15,000 \\
10,000 \\
20,000 \\
20,000 \\
15,000 \\
10,000 \\
15,000 \\
15,000\end{array}$ & $\begin{array}{r}7,500 \\
7,500 \\
7,500 \\
7,500 \\
7,500 \\
7,500 \\
7,500 \\
7,500 \\
7,500 \\
7,500 \\
7,500 \\
7,500 \\
7,500 \\
7,500 \\
5,000 \\
7,500 \\
10.000 \\
12,500 \\
2,500 \\
2,500 \\
5,000 \\
10,000 \\
1,500 \\
1,500 \\
1,500 \\
2,500 \\
- \\
- \\
12,500 \\
15,000\end{array}$ & $\begin{array}{l}1.75 \\
1.75 \\
1.49 \\
1.99 \\
1.07 \\
1.25 \\
.868 \\
1.72 \\
1.66 \\
1.28 \\
1.05 \\
.961 \\
1.29 \\
.688 \\
.991 \\
.863 \\
.988 \\
.896 \\
1.32 \\
1.62 \\
1.31 \\
1.16 \\
1.44 \\
1.18 \\
1.48 \\
1.81 \\
.631 \\
.498 \\
1.11 \\
1.09\end{array}$ & $\begin{array}{l}1.16 \\
1.24 \\
1.03 \\
1.21 \\
.697 \\
.931 \\
.618 \\
.770 \\
.911 \\
.788 \\
.701 \\
.657 \\
.841 \\
.479 \\
.696 \\
.571 \\
.654 \\
.573 \\
.904 \\
1.18 \\
.876 \\
.655 \\
1.03 \\
.837 \\
1.00 \\
1.30 \\
.467 \\
.423 \\
.740 \\
.801\end{array}$ \\
\hline & *(1冖̣ & & & & & & \\
\hline
\end{tabular}


TABLE. I.- Results of Heat Transfer Studies-Continued

\begin{tabular}{|c|c|c|c|c|c|c|c|}
\hline $\begin{array}{c}\text { Run } \\
\text { Number }\end{array}$ & $\begin{array}{l}\text { Pres- } \\
\text { sure } \\
\mathrm{K} \quad \mathrm{Pa} \\
\end{array}$ & $\begin{array}{l}\text { Inlet. } \\
\text { Temp } \\
\circ \mathrm{C} \\
\end{array}$ & $\begin{array}{r}\text { Exit } \\
\text { Temp } \\
0_{\mathrm{C}} \\
\end{array}$ & $\begin{array}{c}\text { Liquid Mass } \\
\text { Velocity } \\
\mathrm{Kg} / \mathrm{m}^{2} \mathrm{hr} \\
\end{array}$ & $\begin{array}{l}\text { Gas Mass } \\
\text { Velocity } \\
\mathrm{Kg} / \mathrm{m}^{2} \mathrm{hr} \\
\end{array}$ & $\begin{array}{c}\text { Effective Thermal } \\
\text { Conductivity } \\
\text { Joules } / \mathrm{m} \mathrm{hr} \text { o } \\
\left(\mathrm{X} 10^{-5}\right)\end{array}$ & $\begin{array}{c}\text { Wall Heat Transfer } \\
\text { Coefficient } \\
\text { Joules } / \mathrm{m}^{2} \mathrm{hr} \text { O } \mathrm{C} \\
\left(\mathrm{X} 10^{-?}\right)\end{array}$ \\
\hline RS-31 & do. & 65.0 & 9.5 & 10.000 & 15.000 & 918 & 630 \\
\hline RS-32 & do. & 56.0 & 16.5 & 20,000 & - & .704 & .482 \\
\hline RS-33 & do. & 62.5 & 21.0 & 20,000 & - & .727 & .520 \\
\hline RS-34 & do. & 61.0 & 13.0 & 20,000 & 5,000 & 1.44 & .905 \\
\hline RS-35 & do. & 59.5 & 23.5 & 20,000 & 10,000 & 1.36 & .799 \\
\hline RS -36 & do. & 61.0 & 11.5 & 20,000 & 12,500 & 1.38 & .748 \\
\hline RS-37 & do. & 60.0 & 11.5 & 20,000 & 15,000 & 1.32 & .748 \\
\hline RS-38 & do. & 57.5 & 16.5 & 25,000 & - & .822 & .499 \\
\hline RS -39 & do. & 53.0 & 18.5 & 35,000 & - & 1.02 & .538 \\
\hline RS-40 & do. & 56.0 & 24.0 & 45,000 & - & 1.25 & .583 \\
\hline RS-41 & do. & 62.0 & 20.0 & 45,000 & 1,500 & 2.38 & 1.16 \\
\hline RS-42 & do. & 59.0 & 13.0 & 25,000 & 1,500 & 1.52 & .801 \\
\hline RS-43 & do. & 63.5 & 16.5 & 35,000 & 1,500 & 2.13 & 1.20 \\
\hline RS -44 & do. & 62.5 & 12.5 & 25,000 & 2,500 & 1.72 & 1.19 \\
\hline RS-45 & do. & 62.5 & 14.0 & 25,000 & 5,000 & 1.48 & .940 \\
\hline RS -46 & do. & 61.5 & 14.5 & 25,000 & 7,500 & 1.43 & .831 \\
\hline RS -47 & do. & 63.0 & 21.0 & 25,000 & 10,000 & 1.54 & 1.06 \\
\hline RS-48 & do. & 61.0 & 14.5 & 25,000 & 12,500 & 1.65 & .752 \\
\hline RS-49 & do. & 63.0 & 17.0 & 30,000 & 2,500 & 1.69 & .959 \\
\hline RS -50 & do. & 61.0 & 16.5 & 30,000 & 5,000 & 1.66 & 1.00 \\
\hline RS-51 & do. & 58.5 & 16.5 & 30,000 & 7,500 & 1.61 & .990 \\
\hline RS- 52 & do. & 60.5 & 16.5 & 30,000 & 10,000 & 1.56 & 1.22 \\
\hline RS -53 & do. & 60.0 & 18.0 & 35,000 & 2,500 & 2.25 & 1.08 \\
\hline RS-54 & do. & 57.0 & 17.5 & 35,000 & 5,000 & 1.94 & 1.06 \\
\hline RS-55 & do. & 57.0 & 23.0 & 30,000 & 10,000 & 1.75 & .908 \\
\hline RS-56 & do. & 55.0 & 23.0 & 35,000 & 10,000 & 1.74 & 1.31 \\
\hline RS-57 & do. & 62.5 & 13.5 & 25,000 & 15,000 & 1.54 & 1.08 \\
\hline RS-58 & do. & 62.5 & 17.5 & 30,000 & 15,000 & 1.44 & 1.10 \\
\hline RS-59 & do. & 62.5 & 15.5 & 30,000 & 1,500 & 1.83 & .921 \\
\hline RS-60 & do. & 58.5 & 17.0 & 30,000 & 12,500 & 1.57 & 1.46 \\
\hline
\end{tabular}


TABLE I.- Results of Heat Transfer Studies-Continued

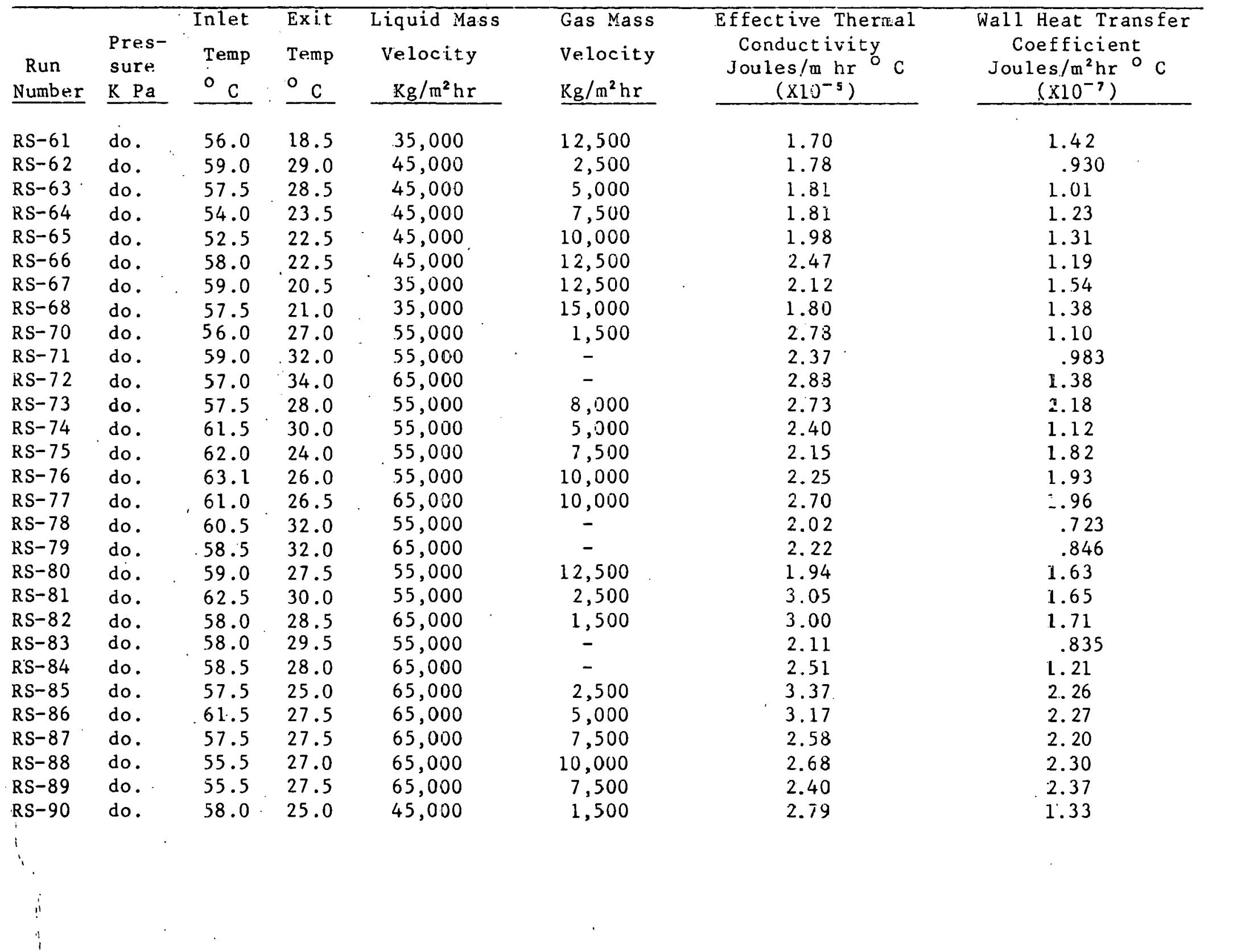


TABLE I.- Results of Heat Trarsfer Studies-Continued

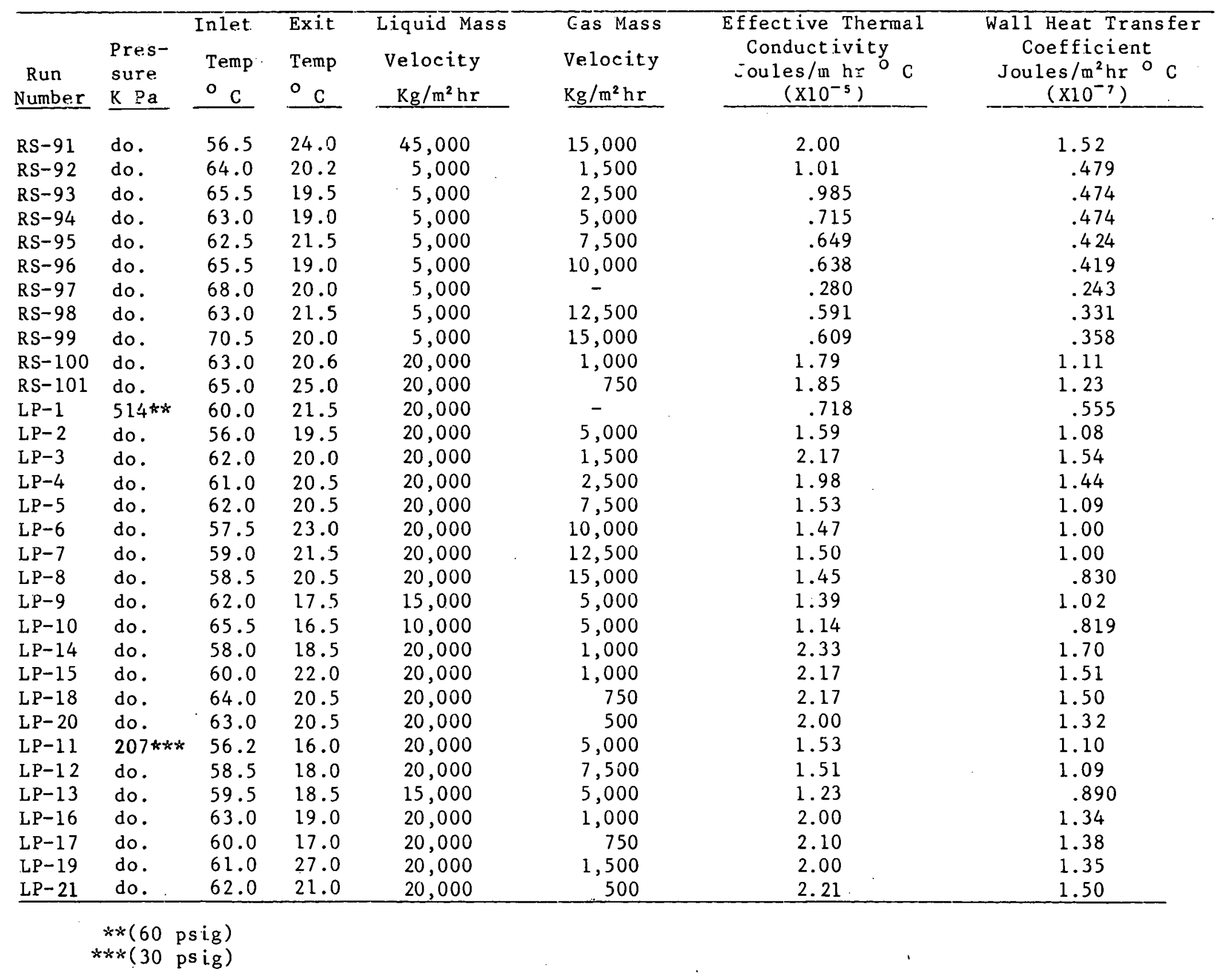

